\title{
Eğitimin Milliyeti: Mülteci Öğrenciler ve Türkiyeli Öğrencilerin Kademelere Göre Değişen Öğrencilik Deneyimleri
}

\author{
LUTFIYE AKTAN \\ ENES SAFAK BILEN
}

Özet

$\mathrm{Bu}$ araştırma Suriyeli mülteci öğrenciler ve Türkiye Cumhuriyeti vatandaşı öğrencilerin aynı sınıfta eğitim görürken öğrenciliği nasıl deneyimlediklerini konu edinmiştir. Birbirinden farklı kültürlerin, sınıfsal konumların, hukuki hakların ve en önemlisi de birbirinden farklı dillerin, eğitim sürecinde nasıl etkileşimler kurduğunu keşfetmeyi amaçlamıştır. Bu bağlamda hukuki statüsü fark etmeksizin Suriyeli öğrenciler ve Türkiyeli öğrenciler ile derinlemesine mülakat yapılmıştır. Mülakatların sonucunda elde edilen veriler eğitim kademelerine göre incelenmiş, eğitim kademelerindeki farklılıklar belirlenmeye çalışılmıştır. Eğitim kademeleri ayırt edilmeksizin çocukların birbirleriyle kurduğu etkileşimde öne çıkan ilk unsur dil olarak belirlenmiş, öğretmenin tutumu ve gelir düzeyi bunu takip etmiştir. Farklılıkların, eğitime ulaşmakta ve eğitimde fırsat eşitliğinin sağlanmasında yıkıcı değil yapıcı bir etken olması konusunda araştırma verileri ekseninde birtakım öneriler sunulmuştur.

Anahtar Kelimeler: Uyum, eğitim, öğrenci, mülteci, göç

- ARASTIRMA MAKALESI-

LUTFIYE AKTAN, aktanlutfiye@gmail.com

Ankara Yıldırım Beyazıt Üniversitesi, Sosyal Politika Tezli Yüksek Lisans Programı ORCID: https://orcid.org/0000-0002-1679-7355

Çocuk ve Medeniyet
ENES \$AFAK BILEN, e.safakbilen@gmail.com

Ankara Yıldırım Beyazıt Üniversitesi, Sosyal Politika Tezli Yüksek Lisans Programı ORCID: https://orcid.org/0000-0002-0929-5445

Gelis Tarihi 05.04.2020 • Kabul Tarihi 28.08.2020 doi: https://doi.org/10.47646/CMD.2020.202 


\begin{abstract}
This research conducted to observe how the Turkish and the Syrian refugee students experience studentship while both were placed in same class.Thus, the study aims to discover how students interact with different cultures, conditions of economic classes, legal rights and different languages. In this context, in-depth interviews were conducted with Syrian and Turkish students. The citizenship status of participants were not taken into account. The data obtained as a result of the interviews were analyzed according to the education levels, and the differences in levels were tried to be determined. According to the data, regardless of the education level, the first factor that stands out in interaction is language. This was followed by teacher attitude and income level. In light of the research, some suggestions have been made in order to make the differences to be a constructive factor in providing access to education and ensuring equality of opportunity in education.
\end{abstract}

Keywords: Integration, education, student, refugee, immigration

\title{
1. Giriş
}

Göç, günümüz dünyasında hızla artan bir olgudur. Türkiye özelinde bakıldığında ise özellikle Suriye'de iç savaşın başladığı 2011 yılından itibaren yaklaşık 4 milyon Suriyeli Türkiye'ye göç etmiştir. 2020 yılı itibariyle Göç İdaresi Genel Müdürlüğü (2020) istatistiklerine göre Türkiye'de kayıtlı 3.586.070 geçici koruma statüsünde Suriyeli bulunmaktadır. Yine 2020 yılı verilerine göre Suriyelilerin 1.672.231'i on sekiz yaşının altındaki çocuklardan oluşmaktadır (Göç İdaresi Genel Müdürlüğ̈̈, 2020). Yani oransal olarak Suriyelilerin \%46'sından fazlası çocuk yaştadır ve aynı zamanda eğitim çağındadır. Türkiye'de bulunan Suriyeli öğrencilerin eğitime erişim sağlama oranı giderek artmakta, 20142015 eğitim-öğretim yılında \%30.42 oranında eğitime erişim sağlayan Suriyeli öğrenci varken 2019-2020 eğitim-öğretim yılında bu oran \%63.29'a ulaşmıştır (T.C. Milli Eğitim Bakanlığı, 2020).

Bunun yanı sıra Suriye'den göç eden insanların hukuksal statüleri de farklılaşabilmektedir. Türkiye Cumhuriyeti sınırları içerisine göç etmiş Suriyeliler, 2011 yılında “misafir” olarak kabul edilmiş, Nisan 2012'de "geçici koruma” statüsü verilmiştir (Çiçeksöğüit, 2017, p. 16). Aynı zamanda 1951 yılında kabul edilen Cenevre Sözleşmesi’ne göre mülteci 
vatandaşı olduğu ülkenin dışında bulunan ve bu ülkenin korumasından yararlanamayan ya da söz konusu korku nedeniyle, yararlanmak istemeyen yahut tabiiyeti yoksa ve bu tür olaylar sonucu önceden yaşadığı ikamet ülkesinin dışında bulunan, oraya dönemeyen veya söz konusu korku nedeniyle dönmek istemeyen şahıs" olarak tanımlanmıştır (Birleşmiş Milletler Mülteciler Yüksek Komiserliği Türkiye Temsilciliği, 1998, p. 68). Buna karşın göçmen kavramı, Türk hukukunda "Türk soyundan ve Türk kültürüne bağlı olup, yerleşmek amacıyla tek başına veya toplu halde Türkiye'ye gelip bu kanun gereğince kabul olunandır" şeklinde tanımlanmıştır (İsmail, Kahraman, \& Aydın, 2018, p. 389). Bu nedenle yazarlara göre Türkiye'de yer alan Suriyeli nüfusun tamamı için göçmen kavramı kullanılmamalıdır (İsmail, Kahraman, \& Aydın, 2018, p. 389). Araştırmaya konu olan çocuklar bu hukuki tanımlamalara göre geçici koruma statüsündedir ancak sosyal durumları, bir siyasi politikadan dolayı yerinden göç eden, başka bir ülkeye sığınan, siyasi yönelen konumunda olduğu için makalede bu öğrenciler mülteci diye adlandırılacaktır.

Bir toplumsal hareketlilik olarak göç kavramının, çoğunlukla uyum kavramları ile birlikte anıldığı görülmektedir. Nitekim Akbaş’a göre "göç edenlerin göç ettikleri yerleşik toplumsal yapıyla karşılaşmaları, kabul görmeleri ya da reddedilmeleri bir takım olası sosyal problemleri beraberinde getirmektedir"(Akbaş, 2019, p. 161). Böylesi önemli bir nüfus Türkiye eğitim sistemini ile bütünleştirilmeye çalışılırken bazı sorunlar ve bazı imkânlar ortaya çıkmaktadır.

Okullar, Türkiyeli çocukların ve mülteci çocukların bir araya geldikleri, sosyal karşılaşmanın yaşandığı kamusal alanların başında gelmektedir. Çocuklar okulda haftalık ortalama 30 saat birlikte zaman geçirirler ve bu süre farklı kademelerde yer alan bütün öğrencilerin sosyalleşmesi için önemli bir süredir. Birinci kademedeki (birinci, ikinci, üçüncü ve dördüncü sınıf), ikinci kademedeki ( beşinci, altıncı, yedinci ve sekizinci sınıf) ve üçüncü kademedeki (dokuzuncu, onuncu, on birinci ve on ikinci sınıf) öğrenciler farklı sosyalleşme düzeylerinde olsalar dahi okul, benliğin sunumunda önemli bir yer teşkil etmektedir. Nitekim Goffman eğitim uzmanı rolünü üstlenen kişilerin oyuncuya arzulanan bir izlenimi nasıl yaratacağını öğretirken bir yandan da gelecekteki seyircilerin rolünü üstlenmek ve cezalar yoluyla uygunsuzlukların sonucunu göstermek gibi rolleri olmasından bahsetmektedir(Goffman, 2004, p.

Çocuk ve Medeniyet 2020/1 153). Akran grupları içerisinde öğrencinin benliğini nasıl ifade ettiği, onun kimliğine ve varoluşuna ilişkin belirleyiciler okul süreçlerinde ön plana çıkabilmektedir. Öğrenci benlik ve kimlik kazanırken bunu öteki 
üzerinden dostça veya düşmanca belirleyebilmektedir. "Ben kimim?" sorusuna vereceği olası cevaplar örneğin "Tiurküm” olduğunda öteki olan Türkler dışında kalan bütün milletler olmaktadır. İşte bu kimlik ve benlik inşasının "ait olduğu grup" dışında kalanlara nasıl yöneldiği ve onları nasıl kurguladığı okul içerisinde önemli bir yer tutmaktadır. "ben Türküm" dediğinde karşısında bir Suriyelinin olması, "ben erkeğim” dediğinde karşısında kız öğrencinin bulunması, "ben sağlıklıyım” dediğinde karşısında bir engellinin bulunması ve bu farklılıklara nasıl yaklaşması gerektiğinin belirlenmesinde çevre ve eğitim son derece önemli bir rol oynamaktadır. Mülteci ve Türkiyeli çocukların aynı akran grubu içerisinde birbirleriyle kurdukları ilişkileri anlamak, onların etkileşim deneyimlerine sşık tutabilmektedir.

Farklı anadillere ve etnik kökenlere sahip bu iki toplumun bir arada yaşama imkânını keşfedilmek amacıyla çalışma yalnızca mülteci çocuklarla sınırlandırılmamış aynı zamanda Türkiyeli çocuklar da çalışmaya dâhil edilerek etkileşimin iki boyutu keşfedilmeye çalışılmıştır. Zira uyum söz konusu olduğunda bunu yalnızca mültecilerin, hâkim gruba uyumu üzerinden okumanın meseleye hiyerarşik bir boyut kazandıracağı düşünülmektedir. Hiyerarşik ilişkide ise uyum ile itaat arasındaki farkın görünürlügüu azalacaktır. "Sosyal mesafe koymak şiddet veya ayrımcılık kadar dikkat çekmese de (en azından siyasa yapıcılar gözünde) aslında ayrımcılığa ve şiddete giden yolun ilk durağı olarak düşünülebilir” (Gürkaynak, 2012, p. 256). Buna rağmen meseleye siyasal tutumları bir kenara koyarak insan hakları perspektifinde yaklaşıldığında ise sosyal mesafe üzerine yeniden düşünülmesi gerekmektedir. Nitekim bugün içinde bulunduğumuz duruma bakıldığında hem Türkiyeli öğrenciler hem de Suriyeli öğrenciler için sosyal temas bir tercih değil zorunluluktur.

\section{Araştırma Sahası ve Yöntem}

Bu makale, bir nitel araştırma ürünüdür. Çocuklarla yapılan çalışmalarda, nitel araştırmanın kullanılması çocuğun dünyasını anlamanın bir yolu değil aynı zamanda çocukla kurulan ilişkilerde belirlenmiş, verili gelen değişkenlerden kurtulmanın bir anahtarı olarak görülmektedir (Akbaş \& Erükçü Akbaş, 2019, p. 160). Çocuğun anlam dünyasının sembollerini öğrenmek, onun dünyasından mevcut verilere bakmak ve problemleri bu şekilde anlamak bu çalışmada nitel yöntem seçmenin temel sebebidir. uygulanmıştır. Bu teknik nitel araştırmanın temel tekniklerinden biri olup 
gerçeğe ilişkin algı, anlam, tanım ve gerçeği inşa edişlere odaklanır (Punch, 2016, p. 166).

Görüşmeler birinci, ikinci ve üçüncü kademede eğitimine devam eden geçici koruma, mülteci veya göçmen çocuklarla ve yine birinci ikinci ve üçüncü kademedeki Türkiyeli öğrencilerle yapılmıştır. Birincil veri kaynağı ise bu çocukların kendisidir. Makalenin temel sorularına çocukların verdiği yanıtlar ekseninde cevap aranmıştır. Katılımcıların çocuk olmasından mütevellit onların anlam dünyalarına girmek, araştırmacı olarak çocukların dünyalarına kabul edilmek için onlarla bu saha çalışması dışında zaman geçirilmeye özen gösterilmiştir. Çocukların dünyalarını keşfetmek amacıyla çocukların her biri evlerinde ziyaret edilmiş, okul gibi total bir kurumdan ziyade ev ortamlarında daha rahat edebilecekleri sebebiyle görüşmeler katılımcıların evlerinde yapılmıştır. Bunun yanı sıra erişim olanağı bulundukça öğrencilerin velileri ve öğretmenleri ile de görüşmeler yapılmıştır.

Çalışma kapsamında 15 mülteci, 16 Türkiyeli katılımcı ile derinlemesine mülakat yapılmıştır. Bu mülakatlar ortalama 1 saat sürmüştür. Yarı yapılandırılmış sorular öğrencilere yöneltilmiş, cevaplar ekseninde yeni sorular doğaçlama olarak belirmiştir. Mülteci katılımcıların 7 tanesi birinci kademe, 6 tanesi ikinci kademe ve 2 tanesi üçüncü kademede eğitim görmektedir. Türkiyeli öğrencilerin ise 5 tanesi birinci kademe, 5 tanesi ikinci kademe, 6 tanesi üçüncü kademede eğitime devam etmektedir. Öğrenciler 6- 18 yaş aralığında olup cinsiyete göre bir dağılım gözetilmemiştir.

Öğrencilerin hepsi Ankara, Pursaklar'da ikamet etmektedir. Bu mekânsal kısıtlama Pursaklar'ın sosyo- ekonomik düzeyi ve Suriyeli Çocukların Türk Eğitim Sistemine Entegrasyonunun Desteklenmesi Projesi (PIKTES) projesi kapsamında uyum sınıflarının varlığıdır. Uyum sınıfına talep, eğitim sürecine dâhil olmak isteyen daha fazla öğrencinin varlığına işaret ettiği için bu çalışmanın sahası olarak Pursaklar'ın belirlenmesinde önemli bir rol oynamıştır. Bunun yanı sıra Ankara'nın kuzeyinde, merkeze en yakın bölge olması, Altındağ'daki çeşitli kentsel dönüşüm faaliyetleri sonucu Pursaklar'ın yoğun olarak göç alması da burayı nispeten kozmopolit bir yer yapmıştır. Bu nedenle de çalışma sahasında böyle bir daraltmaya gidilmiştir.

Örnekleme modeli olarak kartopu örnekleme kullanılmıştır. Mülteci öğrenciler komşuluk ve arkadaşlık ilişkileri vasıtasıyla başka mülteci

Çocuk ve Medeniyet 2020/1 öğrencilere yönlendirilmiştir. Aynı yöntem Türkiyeli öğrenciler için de geçerlidir. Okul dişındaki çocuklarla kurulan temaslar sonucu örneklem zinciri sağlanmıştır.

Eğitimin Milliyeti: Mülteci Öğrenciler ve Türkiyeli Öğrencilerin Kademelere Göre Değişen Öğrencilik Deneyimleri 


\section{Uyum Politikaları ve Atılan Adımlar}

Türkiye'de göçmen meselesi çeşitli politik görüşler tarafından tartışılsa da onların Türkiye'de olduğu bir gerçektir. Aynı zamanda göç bütün dünya devletlerini doğrudan veya dolaylı olarak etkilemekte, bu nedenle de ülkeler ve uluslararası kuruluşlar çeşitli politikalar ve projeler yapmaktadır. Çocukların eğitim sisteminden maksimum fayda sağlaması için eğitim kurumu içerisinde var olan projelerden bir tanesi PIKTES'tir. Türkiye'de Suriyeli öğrencilerin eğitimi öncelikle geçici eğitim merkezleri aracılığıyla yürütülürken Suriyeli öğrencilerin eğitiminin kalıcı bir mesele olduğunun farkına varılmasıyla, Suriyeli Çocukların Türk Eğitim Sistemine Entegrasyonunun Desteklenmesi Projesi (PIKTES) ismi verilen yeni bir uygulamaya geçilmiştir. "PIKTES'ın temel amacı, Geçici Koruma Altındaki çocukların, Türkiye'deki eğitime erişimlerine ve sosyal uyumlarına katkı sağlamaktır"(PIKTES, 2017). Bu kapsamda, Milli Eğitim Bakanlığı'nın Geçici Koruma Altındaki çocukların Türk eğitim sistemine katılımı ve uyumuna yönelik çabalarını desteklemek de Proje'nin özel amaçları arasında yer almaktadır. Projenin faaliyetleri arasında, Türkçe dil eğitimi, destekleme eğitimi, sosyal uyum faaliyetleri ve öğretmen eğitimleri gibi farklı faaliyet alanları bulunmaktadır. Bunun yanı sıra taşıma, kırtasiye, eğitim materyali, psiko-sosyal destek, öğretmen ve okul yönetici eğitimleri, ekipman desteği, aile bilgilendirme seminerleri konusunda da destek sağlamaktadır. Milli Eğitim Bakanlığı'nın 2019/15 sayılı genelgesine göre, 2019-2020 eğitim öğretim yılında uyum sınıfına alınacak yabancı uyruklu öğrencilerin bakanlık tarafından yapılan Türkçe Yeterlilik Sınavından 60 puan altında alması gerekir. Bu öğrenciler Türkçe eğitimini tamamladıklarında Türkiyeli öğrencilerle birlikte eğitim görmeye başlar.

Milli Eğitim Bakanlığı bünyesinde bulunan Özel Eğitim ve Rehberlik Hizmetleri Genel Müdürlüğü'nün ve UNICEF’in ortak hazırladığı “Geçici Koruma Statüsündeki Bireylere Yönelik Özel Eğitim Hizmetleri Kılavuz Kitabı'nda" Suriyelilerin uyumu çeşitli alanlarda değerlendirilmiştir. Kılavuzda sosyal ve kültürel uyumun diğerleri kadar kolay olmadığından, belli bir süreç gerektirdiğinden bahsedilmiştir (T.C. Milli Eğitim Bakanlığı \& UNICEF, 2017). Yine Milli Eğitim Bakanlığı ve UNICEF'in ortaklaşa hazırladığı Geçici Koruma Statüsündeki Bireylere Yönelik Rehberlik Hizmetleri Kılavuzunda hukuki tanımlamalar ve geçici koruma statüsüne ilişkin mevcut bilgiler, geçici koruma statüsündeki bireyler ile ilgili swot analizi, çok kültürlüilük ve çok kültürlü danışma, ölüm, kayıp ve yas, şiddet ve zorbalık, stres bozukluğu, cinsel taciz ve istismardan korunma gibi başlıklar altında öğretmenlere sunulan çeşitli bilgiler mevcuttur. Ayrıca geçici koruma statüsündeki bireylerin, Türkiye'ye gelmelerinden 
itibaren çeşitli ayrımlara maruz kaldığı hatta bu ayrımların nefrete dönüşebildiğinden bahsedilmektedir. Bu ayrımcı dil ve eylemlerden çocuğun eğitim ortamında en az şekilde etkilenmesi, bu kılavuz kitapta acil bir öncelik olarak belirlenmiştir (Şahin \& Karakaş, 2017). Ayrıca Suriyeli insanların, anavatanlarında yaşadıkları savaştan mütevellit bir travma yaşamış olabilecekleri ve rehber öğretmenlerin de geçici koruma statüsündeki öğrencilerle iletişim kurarken birleştirici ve kucaklayıcı bir misyon benimsemeleri önerilmiştir. Yine bu grubun, savaş ve göç sürecinde kayıp, ölüm ve yas gibi kavramlarla karşılaştıkları, bunların bireyler üzerinde yarattığı travmatik durumları belirlemek, saptamak ve gerekli yönlendirmeleri yapmak için rehber öğretmenlere bir yol haritası çizilmiştir(Tanhan, 2017). Geçici koruma statüsündeki kişilere yönelik ayrımcı dil, uyum sürecini riske atan şiddet ve bunun eğitim sürecine yansımasının işlendiği başlıkta eğitim öğretim sürecinde öğrenciler arasındaki farklılıklar ve sembolik sınırlar kimi zaman bir akran zorbalığına dönüşebilmekte, bu da akran zorbalığına maruz kalan çocuğu çeşitli açılardan olumsuz etkilemektedir (Karakaş \& Şahin, 2017). Bu durumun önüne geçmek için riski önceleyici çevre düzenlemelerinin yapılması, şiddettin bir disiplin sorunu olarak karşılık bulması, şiddet önleme programlarının düzenlenmesi gibi öneriler sunulmuştur (Yavuzer, 2011 Akt. Karakaş \& Şahin, 2017). Ayrıca Mavi Kalem Sosyal Yardımlaşma ve Dayanışma Derneğinin "Suriyeli Çocukların Eğitimi Araştırma Raporu” sonuçlarına göre, Suriyeli çocukların Türkiye eğitim sistemine girmeleri ile rehber öğretmenlere büyük bir rol düşmektedir. Çocukların geldikleri ülkede savaşın yıkıcı etkilerini deneyimlemiş olmaları, bulundukları ülkeden göç etmiş olmaları ve travmaya maruz kalmaları bunun en büyük nedenidir. Çözüm olarak ise rehber öğretmenlerin psikososyal destek çalışmalarında aktif olmaları önerilmiştir. Bunun yanında engellilik, yoksulluk, aileden ayrı düşme gibi savaşın sonuçları çocukların eğitime erişmesinde önemli bir problem olarak görülmüş, bu durumun önüne geçmek için de kapsayıcı eğitim anlaşıyışı önerilmiştir. Burada dikkat çeken husus ise uyum sürecinin etkili işlemesi için Milli Eğitim Bakanlığı'nın tüm GEM'leri (Gençlik Eğitim Merkezi) kapatması ve geçici koruma statüsündeki öğrencileri Milli Eğitim Bakanlığı'na bağlı okullara yönlendirmesidir. Yine bu rapora göre Suriyeli öğrencilerin meslek liselerine yönlendirilmesi de hedeflenen politikalar arasındadır(Mavi Kalem Sosyal Yardımlaşma ve Dayanışma Deneği, 2019).

\section{5}

Çocuk ve Medeniyet 2020/1

\section{Bulgular}

Yapılan görüşmeler neticesinde elde edilen bulgular birkaç farklı başlık altında incelenmelidir. Nitekim çocukların dünyasına ilişkin veriler politik 
sonuçlara uyumla ilgili olduğundan eğitim-öğretime devam eden çocukların birbirleriyle etkileşimlerinde ortaya çıkan birçok faktör vardır.

\subsection{Anlaşmanın İlk Adımı: Dil}

Mülteci çocukların Türkçe bilme düzeyi, yerli öğrenciler ile uyumları açısından son derece belirleyici bir bulgudur (Taştan \& Çelik, 2017; Özyürek, Kapçı, \& Yılancı, 2019; Özger \& Akansel, 2019).Mülteci katılımcıların Türkiyeli öğrenciler ile uyumunda hemen hepsi dil bilmenin Türkiyeli öğrencilerle anlaşmada bir kilit nokta olduğunu söylemiştir. PIKTES kapsamında uyum sınıfına alınan öğrenciler bu süreci daha kolay atlatsalar da birtakım prosedürler gereği bütün mülteci çocuklar bu uyum sınıfında eğitim alamamaktadır. Özellikle birinci sınıfta okuyan çocukların Türkçeyi öğrenme sürecinde bazı problemler yaşadığı ve bu problemlerin genelde sınıf öğretmeni tarafindan çözüldügü belirtilmiştir. Birinci kademeye henüz yeni başlayan bir mülteci öğrenci, arkadaşlarının kalemini çöpe attığı, yemeğine tükürdüğü gibi birtakım olumsuz muamelelere maruz kaldığını anlatmıştır. Bu sorunun çözümü için öğrenci doğrudan öğretmenle iletişime geçememiş, sorunun çözümü velinin öğretmen ile görüşmesi yolu ile sağlanmıştır. Yapılan kötü muameleye itiraz edememe, öğretmen ile doğrudan iletişim kuramama aslında yaşanan problemlerin ilk adımıdır.

Ancak uyum sınıfında eğitim görüp, Türkçe eğitimini tamamlayan öğrenciler Türkiyeli öğrencilerle aynı sınıfta okumaya başladıklarında birinci kademedeki öğrenciler için daha kaynaşmış bir öğrencilik biçimi gözlenmiştir. Örneğin sınıf içerisinde Türkiyeli öğrencilerin mülteci öğrencilerle aynı sırada oturduğu, teneffüs saatlerinde birlikte zaman geçirdiği, beden eğitimi gibi birinci kademe için oyun odaklı derslerde öğrencilerin yine diğer mülteci öğrencilerle birlikte olduğu saptanmıştır. Mülteci çocuklara en yakın arkadaşın kim diye sorulduğunda onlar genellikle Türkiyeli öğrencilerin isimlerini vermiştir. Uyum sınıfında eğitim görüp, Türkiyeli çocuklarla birlikte eğitim gören çocukların doğrudan bir olumsuz muameleye maruz kalmadığı gözlemlenmiştir. Ancak bu durum Türkçeyi iyi kullanma ölçütüne göre değişebilmektedir. Bu konuda bir Türkiyeli öğrenci, mülteci arkadaşlarıyla sohbet ettiklerini, daha çok Türkçe bilse daha çok sohbet edebileceklerini söylemiştir.

Mülteci çocukların teneffüs saatlerine ilişkin gözlemlerde ise, genellikle iki kişiden fazla gruplar halinde oyun oynadıkları gözlemlenmiştir. Birinci kademedeki sınıf öğretmenleri, birinci kademede eğitim gören mülteci çocukların etkileşim kurduğu Türkiyeli çocukları genellikle yoksul veya ders başarısı düşük çocuklar olarak tanımlamıştır. Bu durum bize şunu 
anlatmaktadır: Çocuklar arasında tanımlanmamış bir farklılık vardır. Keza mülteci çocuklar Suriye'den neden geldiklerine ilişkin detaylı bir bilgiye sahip değildir. Çocukların tanımlayamadığı bu farklılık, farklılığı anlamalarına engel olmamıştır. Yani çocuklar, mülteci çocukların kendilerinden farklı olduğunu anlamakta fakat bu farklılığı bir ayrıma dönüştürmemektedir. Fakat farklılığın farkında olma, mülteci çocuklar ile yerli çocuklar arasına ince bir çizgi çekmekte ve mülteci çocukları sınıfta hali hazırda ötekileştirilmiş çocukların yanına itmektedir. Fakat bu o kadar düşük seviyededir ki ancak mülteci çocuklardan bağımsız yapılan gözlemler ve görüşmeler sonucunda ortaya çıkmıştır.

Türkiyeli çocukların mülteci çocuklar hakkındaki görüşleri ise birinci kademe için aslında pek net değildir. Yani mülteci çocukların neden burada oldukları, kim oldukları, etnik kökenleri vb. durumlara ilişkin pek fazla bilgi sahibi olmadıkları ortaya konulmuştur. Mülteci, çocukları çok sevdiklerini, gitmelerini istemediklerini belirtmiş olsalar da aslında onlarla bir alanı paylaşmak konusunda çekimser kaldıkları veya bir görüş beyan etmedikleri görülmüsstür. Örneğin mülteci arkadaşınla hangi oyunları oynuyorsun sorusuna çocuklar genellikle sessiz kalmış veya kalabalık bir grupla oynanan futbol, mendil kapmaca gibi oyunları saymıştır. Bilindiği üzere bu oyunlar sözel iletişim kurmayı pek gerektirmeyen, genelde fiziksel aktivite içeren oyunlardır.

Türkiyeli çocukların mülteci çocuklar hakkındaki verilerinde dil, belirleyici bir roldedir. Türkiyeli çocuklar, Türkçeyi konuşup anlayabilen öğrencilerin varlığını kabul etmekte ve onu bir özne olarak dikkate almaktadır. Ancak Türkçe öğrenememiş mülteci çocuklar hakkında "bize alışamadı, buraya alışamadı" gibi yorumlar yapmaktadır. Dolayısıyla birinci kademede dil biliyor olmak aslında mülteci çocuğun bir özne olarak kabulünü sağlayan en önemli faktördür. Bu nedenle Türkiyeli çocuklar Türkçeyi anlaşabilecek düzeyde bilmeyen öğrenciler için herhangi bir görüş bildirmemiştir. Fakat mülteci arkadaşın ile aynı sırada oturmak ister misin diye bir soru yöneltildiğinde ise çocuklar genellikle ya istemediğini söylemiş ya da öğretmen isterse otururum gibi zorunluluk açısından yaklaşmıştır. Bunun sebeplerini ise mülteci arkadaşının arka sırada oturması, onunla konuşamaması, mülteci arkadaşının dersi anlamaması, kötü koktuğu gibi genellikle fiziksel unsurlar üzerinden göstermiştir. Oyun aktivitelerinde Türkiyeli çocukların genellikle kendi yakın arkadaşları ile oynadığı, mülteci arkadaşları ile oynadığı takdirde diğer arkadaşlarının küseceği endişesi taşımaktadır. Yani aslında arkadaş grupları kendi içlerinde kapalı gruplardır ve bu arkadaşların başkalarıyla oyun oynaması grup ruhuna aykırı bir 
durumu ifade etmektedir. Dolayısıyla bu mültecilik olgusundan ziyade grup dinamikleri ile ilişkilidir.

İkinci kademe öğrencileri için veriler bu konuda bize daha net bilgiler vermektedir. Nitekim ikinci kademedeki çocukların hepsi Türkçeyi konuşup anlayabilecek düzeydedir. Bu nedenle aslında dil burada belirleyici bir etken olmaktan çıkmaktadır. Fakat bir yabancı olarak, Türkçeyi düzgün kullanmak veya argo tabir edilen sözcükleri kullanmak konusunda çeşitli anlamlar belirmektedir. Yani artık mesele Türkçeyi konuşmak yerine Türk gibi Türkçe konuşmak olmuştur. Kullanılan dile hâkim olmak sadece gramer kurallarından ibaret değil artık kültüre hâkim olmakla ilişkilendirilir. Aslında tam olarak bu noktada dilin, tamamlanmış bir yapıt değil, bir etkinlik olduğu gerçeği ortaya çıkar (Humboldt, 1949 Akt. Kılıç, 2008, s. 48).Böyle olunca mülteci çocukların Türk çocuklarla kurduğu ilişkiler yabancı-yerli ayrımından Suriyeli-Türk ayrımına dönüşür. Nitekim ikinci kademedeki mülteci çocuklar kimi zaman Suriye'ye gidip gelmekte veya göç hikâyesini bilmektedir. Türkiye'deki mültecilere ilişkin tutumun farkındadırlar. Bu durum bize bir "Suriyeli” kimliği anlatmaktadır.

İkinci kademede çocukların birbirleriyle kurdukları ilişkiler bu bağlamda şekillenmektedir. Çocukların her biri bir özne olarak etkileşim içerisindedirler. Mülteci çocukların ilişkisi dostluk ve düşmanlık olmak üzere iki şekilde gerçekleşir. Bu düşmanlık ilişkisi ya kavgayla başlamakta ya da kavgayla bitmektedir. Bu kavgaların sebebi ise genellikle dili yanlış kullanmak ile ilişkilidir. Örneğin ikinci kademe öğrencilerden bir tanesi, kendisine "zil çaldı sınıfına gir hemen" diye çıkışan arkadaşına "sanane lan" demiş, bir argoyu yanlış yerde kullanmasından mütevellit, Türkiyeli arkadaşı ona elindeki kâğıtlarla vurmuştur. Aynı şekilde bir başka mülteci öğrenci, Türkiyeli arkadaşı tarafından konuşmasının taklit edilmesi suretiyle bir olumsuz muameleye maruz kalmıştır. Bunun yanında kurulan dostluk ilişkileri ise yardımlaşma üzerinden kurgulanmıştır. Öncelikle hiçbir mülteci öğrenci ikinci kademede en yakın arkadaşını bir Türkiyeli olarak belirlememiştir. İkinci kademedeki mülteci öğrencilerin en yakın arkadaşları diğer mülteci çocuklardır. Fakat Türkiyeli öğrencilerle dostluk ilişkileri bir yardımlaşma ile başlamaktadır. Bu yardımlaşma yiyecek, para gibi nesneler olabileceği gibi derslerle ilgili de olabilmektedir. Örneğin ikinci kademdeki bir öğrenci Türkçe dersinin kötü olduğunu ve Türkiyeli arkadaşlarının onu çalıştırdığını söylemiştir. Bir başka öğrenci ise ders konusunda arkadaşlarından yardım istediğini ancak arkadaşlarının ondan herhangi bir yardım istemediğini söylemiştir. Yani ikinci kademedeki öğrencilerin birbirleriyle olan ilişkilerinde dilin rolü kültürlenme ile ilişkilidir. Dilin nevi 
şahsına münhasır özellikleri üzerinden kurulan bizlik ilişkisi bu çocuklar arasındaki etkileşimde önemli bir yer tutmaktadır.

Aynı durum Türkiyeli öğrenciler için konuşulduğunda ise mülteci çocuklarla ilişkilerde dilin benzer bir işlevi vardır. Dilin etkin kullanımının ders başarısına etkisi Türkiyeli çocukların mülteci çocuklarla ilişkisinde önemli bir roldedir. Yani mülteci bir çocuğun ders başarısı yüksekse ve Türkçeyi daha etkin kullanıyorsa bu durum bir özne olarak kabulünü önemli ölçüde etkiler. Bunun iki sebebi vardır, birincisi bu dile ait mecazların, deyimlerin, ikincil anlamların kullanılması yabancılığı ortadan kaldıran bir unsurdur. Çünkü Bauman'a göre, “yabanciların dikkate değer özelliği büyük oranda bildik olmamalarıdır. Bir kişiyi yabancı kabul etmek için öncelikle onun hakkında hiç olmazsa birkaç şey bilmem gerekir. Onlar adeta ne yakındır ne de uzaktadır. Ne bizim parçamızdır ne de onların bir parçası. Ne düşman ne de dostturlar”(Bauman, 2018, p. 73). Bu nedenle yabancılık, çocuklar için tam olarak aşılması gereken yerdir.

Çocuklar Türkçeyi bir gramer sisteminden öteye götürüp Türkçeyi o bölgenin diğer unsurları ile birlikte kullandığında o grubun normlarını da kabul etmiş olmaktadır. Dolayısıyla İç Anadolu Bölgesi’nde kullanılan birtakım yerel ifadeler yerinde kullanıldığında Türkiyeli öğrenciler ile daha samimi ilişkiler gerçekleştirmektedir. Örneğin bir ikinci kademe öğrencisi, mülteci arkadaşının tanımadı̆̆ bir erkekten "dayı" diye bahsediyor oluşunu buna örnek göstermiştir. İkinci bir etken ise Türkçeye hâkim olmanın dersi anlamayı kolaylaştırdığı ve bu nedenle ders başarısının yükselmesinin arkadaşlık ilişkilerindeki önemli pozisyonudur. Bu şekilde öğretmenler tarafından kabul görüp eğitim sistemine aktif olarak dâhil edilen öğrenciler, öğretmen otoritesi tarafından kabul edilmiş bir öğrencinin ötekileştirme olasılığını düşürmektedir. Türkiyeli öğrencilerden elde edilen verilere göre, ders başarısı yüksek olan mülteci öğrencilerle eşit olduklarını ve onları benimsedikleri ortaya çıkmıştır. Burada ise resmi ideoloji ile uyum içerisinde olmanın yanı sıra öğrencinin öğretmen tarafindan kabul edilmesi ve benimsemesi üzerinden gelişen "mülteci öğrencileri tehlikesiz olarak adlandırma" çabası okunabilir. Buna ilişkin Illich, okulları hayat görüşlerini belirleyen, yaşamı yönlendiren ve yasallığın niteliğini tanımlayan kurumlar olarak tanımlar (Illich, 2006). Ayrıca Baker, normal bir çocuk olmak için eğitim sistemine uyum gösterilmesi gerektiğini söyleyerek, mülteci çocukların eğitim sistemi içerisindeki başarılı olması konusunun bir analizini yapmış olur (Baker, 2000, p. 46). dil faktörüne bağlı olarak başarı oranları düştüğünde bu daha fazla 
ötekileştirilmeye maruz kaldıkları anlamına gelmektedir. Örneğin ikinci kademeden bir öğrenci, Türkçe dersinin iyi olmadığını fakat doğru bildiği sorular dahi olduğunda öğretmenin onu desteklemediğinden dolayısıyla da öğrencilerin onu etkisiz bir eleman olarak kabul ettiklerinden bahsetmiştir. Arkadaşlarından seni çalıştırmasını istemedin mi diye sorulduğunda ise çekinip söyleyemediğini söylemiştir.

İkinci kademe öğrenciler için dilin rolü yerel ifadeler ve dile mahsus argümanların öğrenilmesi üzerindendir. Öğrencilerin bu özel ifadelerin kullanımında ne kadar etkin olduğu onların birbirleriyle ilişkilerini etkilemektedir. Öğrencilerin, Türkiyeli arkadaşların olduğu grubun bir üyesi olabilmesindeki ilk adım işte bu ifadelerin aktif ve yerinde kullanımına bağlıdır. İkinci olarak ise dili anlama becerisine bağlı olarak okulda gösterdiği başarı ve öğretmenin kabulü üzerinden gelişmektedir.

Üçüncü kademeye gelindiğinde ise dil kullanımı milliyetçilik üzerinden şekillenir. Üçüncü kademedeki mülteci öğrencilerin hemen hepsi o yaşa kadar Türkçeyi öğrenmişlerdir ancak bu defa dil, bir milletin semboller dizisi olarak karşımıza çıkmaktadır. Öncelikle görüşmeye katılan bütün üçüncü kademe mülteci öğrenciler İmam Hatip Lisesi veya Meslek Lisesinde eğitim görmektedir. Bu öğrencilerin Anadolu Lisesi, Fen Lisesi veya Sosyal Bilimler Lisesi gibi yüksek puan gerektiren yerlerde olmadığı görülür. Arkadaşlık ilişkilerinde dil önemli bir faktör olsa da bunun yanında asıl önemli olan kimliktir. Yani bir mülteci öğrenci dili iyi kullanıp kullanmamasından bağımsız bir şekilde sadece mülteci olduğu için birtakım olumsuz muameleye maruz kalabilmektedir. Bu nedenle üçüncü kademedeki öğrenciler genellikle sessiz kalmayı, toplumsallaşmamayı ve akran grupları ile iletişim kurmamayı tercih etmiştir. Birinci ve ikinci kademeye göre dil bilmenin belirleyiciliği azalmıştır. Örneğin bir lise öğrencisi, yan sınıftaki öğrencilerin kendisine Suriyeli olduğu için saldırdığını, kendisini sınıf arkadaşlarının kurtardığını belirtmiştir. Kavga etmek için Suriyeli olmanın yetiyor olması üçüncü kademedeki akran zorbalığının net bir göstergesidir. Aynı zamanda üçüncü kademeye geçen mülteci öğrencilerin azlığı, sınıf mevcudu içerisinde ya bir ya da hiç mülteci öğrenci bulunmamasına neden olmuş dolayısıyla mülteci öğrencilerin sınıfta “yalnız” kalmaları veriler arasındadır. Bu yalnız kalma meselesi ise bize aslında bir aidiyet oluşmadığını ve çeşitli ötekileştirmeye maruz kaldıklarını belirtir.

Üçüncü kademede öğrenim gören Türkiyeli öğrenciler için dil söz konusu

Çocuk ve Medeniyet 2020/1 bile olmamıştır. Bu öğrenciler dilin önemine vurgu yapmamışlardır. Onları

Suriyeli olarak tanımladıkları ve onlarla kurdukları ilişkileri doğrudan

Suriyeli olmak üzerinden tasarladıkları dikkat çekmektedir. Dilin kendine 
has niteliklerini biliyor dahi olsalar Suriyeli mülteci çocuklarla ilişkilerde bu bir belirleyici değildir. Artık dili bütün yönleriyle kullanmak üzerine bir ilişki biçimi gözlemlenmemiştir. Bunu ise Bauman'ın “bildik olanın dışındaki koşullar, edinilmiş becerilerin değerini düşürür ve böylelikle karışıklı̆̆ın sorumlusu yabancilarda odaklanan bir rahatsızlı, belli belirsiz bir öfke hatta düşmanlı duygusuna neden olur. Yabancılarn tarzları onların geriliklerinin ya da küstahlıklarının kanıtı olarak görülür, yabancıların kendileri de bozguncular olarak algılanır. Insan onların ayr tutulmasin ya da ortadan kaldırlmasin ister"(Bauman, 2018, p. 193) ifadesi ile doğrudan ilgili olduğu görülür.

\section{2. Öğretmen Faktörü}

Mülteci çocukların ve Türkiyeli çocukların birbirleriyle kurdukları ilişkilerde dış çevrenin etkisi yine önemli bir faktördür. Kültürlenmenin başladığı yer olan aile ve devamındaki okul çocukların kimlik inşasında önemli bir rol oynar (Althusser, 2017; Çayır, 2014). Ayrıca aile ve öğretmenlerin bir otorite ve yol gösterici oluşu çocuklar için belirleyicidir.

Birinci kademedeki mülteci öğrenciler, öğretmenlerini sorun çözen yegâne kişi olarak tanımlamıştır. Özellikle uyum sınıfında eğitim almayan ve sorun yaşayan öğrenciler, öğretmen ile çözüm bulabilmişlerdir. Bu sebeple öğretmenin mültecilere yönelik bakışı önem arz etmektedir. Ancak bu konuda birinci kademede eğitim veren sınıf öğretmenlerinin mülteci öğrencilere yönelik hiçbir ayrımcı veya ötekileştirici ifade kullanmamış olması ve mülteci öğrencilerin, öğretmenlerine besledikleri sevgi şaşırtıcı düzeydedir. Hatta veliler ile sürekli iletişim halinde olan bu öğretmenler, mülteci öğrencilerin velileri tarafından da saygı duyulası, kutsal kelimeler ile sıklıkla birlikte anılmaktadır. Öğretmenlerin bu süreçteki rolü mülteci öğrencilerin uyumunu kolaylaştırmaktadır. Örneğin birinci kademede bir sınıf öğretmeni, mülteci çocuklar ile Türkiyeli çocuklar arasında bir tatlı rekabet oluşturduğunu, bu rekabet süresinde hiç Türkçe bilmeyen mülteci öğrencilerin çok kısa bir sürede Türkçeyi anlama, okuma ve yazma konusunda oldukça iyi bir yere geldiğinden bahsetmiştir. Bu rekabet sonucunda da mülteci çocukların ve Türkiyeli çocukların birbirlerinden hiç ayırt edilmeyecek kadar sıkı ilişkiler kurduğundan bahsetmiştir. Aynı zamanda mülteci öğrencilerin öğretmenlerle kurdukları ilişki sadece okuldan ibaret değil, okul dışındaki hayatlarında veya bir okul değişikliği söz konusu olduğunda da öğretmenleri ile irtibatlarının devam ettiğinden bahsetmişlerdir. Buna rağmen öğretmenlerin mülteci öğrencilerden bahsederken genellikle yoksul öğrencilerle, öğrenim güçlüğü olan kaynaştırma öğrencileriyle birlikte andığı ve bu dezavantajın örtük bir biçimde dile getirildiği gözlemlenmiştir. Fakat bu dezavantajların birer 
ayrıma dönüşmemesi için öğrencilerin birbirleriyle zorunlu olarak temas etmelerini sağlamak için çaba harcadıklarını da sıklıkla dile getirmişlerdir. Örneğin sınıf öğretmenlerinin, oturma düzenini periyodik olarak değiştirdiğini ve dezavantajlı öğrenci gruplarının diğerleriyle temas edecek biçimde ayarladığını, sınıf başkanlığı seçimi gibi aktivitelerde bu öğrencileri de aday yaptığı gibi birtakım çabalar söz konusudur. Öğretmenlerin bu çabalarının bir sonucu olarak da birinci kademede ayrımlar yok denecek kadar azdır.

Bunun yanı sıra birinci kademedeki öğrenciler için notlandırma sistemi sadece sınavlardan ibaret değildir. Nitekim birinci ve ikinci sınıflar için sınav yerine performans ölçeği vardır. Bu nedenle aslında başarının net bir puan üzerinden hesaplanmıyor oluşu çocukları belirli bir başarı düzeyine göre konumlandırmaz. Böylece ders başarısı göreceli olabilmektedir. Ancak birinci kademedeki Türkiyeli öğrencilerin, mülteci öğrenciler ile arkadaşlık ilişkisi kurarken ders başarısı ve öğretmenin sevgisini kazanabilmiş olma durumunu dikkate aldıkları gözlenmiştir. Öğretmen tarafından beğenilme ve takdir edilme onların sosyal grup oluşturmalarında gizli bir etkendir.

İkinci kademedeki öğretmenler için ise bu kez branş öğretmenleri değişkeni göze çarpmaktadır. Her derse giren bir sınıf öğretmeni yerine farklı derslere giren branş öğretmenlerinin mültecilere ilişkin görüşlerinin öğrencilere yansıdığını görmekteyiz. Örneğin Türkçe öğretmeni tarafından sevilmeyen bir öğrenci kimi durumlarda bir hizipleşmeye maruz kalabilmektedir. Aynı zamanda sosyal bilimleri konu edinen derslerde hâkim ulus-devlet paradigmasının öğretmen vasıtasıyla öğrenciye aktarımı öğretmenin dünya görüşüne göre farklılaşabilmektedir. Bu durum mülteci öğrenciler ve Türkiyeli öğrencilerin ilişkilerini öğretmenin dünya görüşüne bağlı olarak da etkileyebilmektedir. Öğretmenin bir rol- model olarak benimsendiği durumlarda öğretmenin dünya görüşü de öğrenciye aktarılabilmektedir. Örneğin ikinci kademedeki bir sosyal bilgiler öğretmeni Arapların Osmanlı'yı yarı yolda bırakıp İngilizlerle işbirliği yaptığını söylemiştir. Bu durum resmi tarih içerisinde geçerli bir bilgi olsa da çocuklarda Araplara ve dolayısıyla mülteci çocuklara karşı bir önyargı meydana getirmiştir. İkinci kademedeki mülteci öğrenci bu duruma oldukça üzüldüğünü dile getirmiştir. Bu ise örtük ideolojinin aktarımı ile doğrudan ilişkilidir (Althusser, 2017; Çayır, 2014; Apple, 2006). Aynı zamanda Türkiyeli öğrenciler ekseninden de resmi ideolojinin aktarımı sürecinde bu tür kültürlenmeler göze çarpar.

Türkiyeli öğrenciler, derslerin yanı sıra Araplar hakkında çevrelerinden duydukları bilgiler ekseninde mülteci öğrencilerle aralarına bazı sınırlar çekmektedir. Bu bilgilerin herhangi bilimsel veya resmi bir yanı olmasa da mülteci öğrencilere bakışı etkileyecek boyuttadır. Örneğin ikinci kademede 
eğitim gören Türkiyeli bir öğrenci Hz. Peygamberin “ben Arap'ım, Araplar benden değil" dediğini referans göstererek mülteci arkadaşlarını sevdiğini ama genellikle diğer arkadaşları ile zaman geçirdiğini belirtmiştir. "Bu dediğini nereden öğrendin?” diye sorulduğunda ise ağabeyinden duyduğunu söylemiş; öğrenci bilginin doğruluğunu teyit etmek için bir araştırma yapmamıştır. Ancak böyle bir durumda din kültürü, sosyal bilgiler, Türkçe gibi ders öğretmenlerine büyük bir görev düşmektedir. Bu nedenle ikinci kademede ders başarısı ve öğretmen ilişkisi yine birlikte ilerlemektedir. Bir öğretmen resmi ideoloji doğrultusunda Arapların sözüm ona kötü bir grup olduğunu savunabilir. Bunu derste doğrudan veya dolaylı olarak aktarabilir. Bu aktarım sırasında Türkiyeli öğrenciler açısından Arap mültecilere karşı bir önyargı oluşabilir. Mülteci öğrenciler ise değersiz veya Türkiye vatandaşları karşısında ötekileştirilmiş bir grup olmayı kabul edebilir. Okul ortamında ders başarısından ziyade ideolojik tutumların öncelendiğini düşünmesi, zaten mülteci oldukları için ötekileştirilen bu grup için "kendi kendini gerçekleştiren kehanet" vazifesi görebilir. Mülteci öğrenciler böyle bir durumla karşılaştıklarında tepki vermemekte, durumu görmezden gelmekte ve bununla mücadele yolu geliştirmemektedir.

Üçüncü kademede ise durum biraz daha farklılaşmaktadır. Veriler mülteci çocuklar ve Türkiyeli çocukların bir arada bulunduğu bir ders ortamında, öğretmenin mülteciler konusundaki en ufak bir söylemi dahi olduğunda bütün gözlerin mülteci çocuğa çevrildiğini göstermektedir. Örneğin öğretmen, mültecilerin zamanı geldiğinde kendi ülkelerine gitmeleri gerektiğini söylediğinde -ki bu mültecilerin de istediği bir durum olabilirgenellikle büyük tartışmaların fitilini ateşleyebilmektedir. Hatta ve hatta öğretmenlerin birleştirici tavırlarının derslerde göçmen karşıtı öğrenciler tarafından sıklıkla reddedildiği, bu durumun öğrencilerin birbirleriyle kurdukları ilişkileri doğrudan etkilediği ortaya konulmuştur. Türkiyeli öğrencilerin bir kısmı için de bu geçerlidir. Öğretmenin veyahut müfredatın bir aktarıcısı olan öğretmenin tavrı onların göçmen çocuklarla olan ilişkilerine doğrudan etki eder. Özellikle kız çocuklarında mülteci çocuklara karşı ayrımcı muamele veya kötü bakış mülteci çocukları anlamaya, onlarla iyi ilişkiler kurmaya yöneltse de oğlan çocukları için ayrımı tetikleyici bir unsur olarak devreye girmektedir. Bu cinsiyet ayrımında temel faktör elbette toplumsal cinsiyet rolleri ekseninde yürümektedir. Oğlan çocukları hâkim erkeklik kodları nedeniyle kendilerini devlet ve siyaset konularında daha yetkin, gerektiğinde savaşçı ve vatanını savunucu bir kimlikle ilişkilendiriyor olabilir.

Üçüncü kademe Türkiyeli öğrencilerin, derslerde Arap-Türk siyasi ilişkileri, mülteci karşıtlığı ve farklılıklara ilişkin konularda öğretmenin tavrı 
değişmeksizin sanki mülteci öğrenci bütün bir Suriye toplumunu temsil ediyormuşçasına bir muameleye tabi tuttukları veriler arasındadır. Ancak öğretmenlerin bu konudaki şahsi görüşleri de kimi zaman bu ayrımı tetiklemekte, alevlendirmektedir. Kız çocukları bu konulara genellikle uzak kalmayı veya daha insancıl ilişkiler geliştirmeyi tercih ediyor olsalar da oğlan çocuklarının nefret söylemleri ciddi boyutlara ulaşmaktadır. Bu söylemler arasında, mültecilerin ülkelerinde savaşmadıkları, vatanlarını sattıkları, kaçtıkları, Türkiyeli askerlerin Suriye topraklarında savaşırken onların kayıtsız kaldığı önemli oranda dikkat çeker. Bunun yanı sıra mültecilere devlet tarafından çok para verildiği, onlara üniversiteye girişte ve hastanelerde öncelik tanındığı, Türkiye'nin mültecilere sağladığı imkânların kendilerine sağlanmadığı gibi eşitsizliklerin ve ayrıcalıkların olduğu; onlar geldikten sonra suç oranlarının arttığı, sürekli kavga çıkarttıkları, insanları öldürdükleri veya tecavüz ettikleri, uyuşturucu sattıkları gibi çeşitli suçlar karşısında günah keçisi ilan etme gibi durumlar söz konusudur. Ancak üçüncü kademedeki çocuklar kendi aralarında bu konuda uzlaşmış değillerdir. Yukarıda da belirtildiği gibi mülteci çocuklara karşı herhangi bir sevgisi veya nefreti olmayan öğrenciler olabildiği gibi onlara bu tür muameleler yapıldıktan sonra veya bu tür görüşler karşısında mülteci öğrencileri anlamaya ve sevmeye yönelik tutulumları olan Türkiyeli öğrenciler de vardır.

Mülteci öğrenciler açısından bu durum iftiraya maruz kalmaya, fiziksel şiddet girişimlerine kadar gidebilmektedir. Bu durum elbette ders başarısını etkilemektedir ancak ders başarısı onlar için bir belirleyici değildir. Nitekim mülteci çocuklar derslerinin iyi olduğunu dile getirmiştir. Derslerde başarılı olmak arkadaş olmak için yeterli veya öncü bir sebep olmaktan çıkmıştır. Üçüncü kademede de resmi ideolojinin mültecilere bakışı önemli bir etkendir (Apple, 2006; Althusser, 2017; Çayır, 2014).

\subsection{Gelir Düzeyi ve Yoksulluk Etkisi}

Tahmin edilebileceği üzere mülteciler sıklıkla düzensiz gelir, yasal olmayan mesai saatleri, güvencesiz, sağlıksız, sigorta sisteminden yoksun şekilde kayıt dışı olarak çalışmaktadırlar. Zaten göçün getirdiği hali hazırda bir yoksulluk varken buraya geldiklerinde çalışma hayatında yaşadıkları problemler onları ekonomik bakımdan da zorlu bir hayatın içerisine atmıştır(Taştan \& Çelik, 2017; Akbaş, 2019). Bu durum ise çocuklarda yardımlaşma duygusunu ön plana çıkartmış olsa da kimi durumlarda "kaçınılması gereken kişis" anlamı yüklediği söylenebilir.

Çocuk ve Medeniyet 2020/1
Birinci kademede eğitim gören mülteci çocuklar aslında yoksulluk kaynaklı bir ayrım olup olmadığının farkında değildirler. Mülteci öğrenciler bu 
nedenle bir ayrıma maruz kaldığını iddia etmemiştir. Fakat veri toplamaya devam ettikçe aslında bu durumun doğrudan değil dolaylı yollarla bir ayrıma sebep olduğu verisi ortaya çıkmıştır. Örneğin mülteci çocuklar bir yardım almıyorlarsa ders materyallerine erişimde zorluk çekmekte ve ders materyalleri konusunda bir tercih yapmaya zorlanmaktadır. Defter almayı fon kartonu almaya tercih etmek gibi. Aslında böyle bir durum yani bir tercih yapmak zorunda kalmak onları okul içerisindeki eğitimöğretim faaliyetlerine tam anlamıyla katılamadıklarını gösterir. Ancak sınıf öğretmenlerinin böyle bir durumun önüne geçmek için bu tür materyalleri alamayan öğrenciler için temin ettiği yine bulgular arasındadır. Fakat yine de öğretmenler bunları tedarik etmek zorunda değillerdir ve derslerin tamamına aktif katılım öğretmenin inisiyatifinde gelişmemelidir. Aynı zamanda beslenme saatleri birinci kademe öğrenciler için ayrımların ortaya çıktığı bir saattir. Burada öğrencilerin ne yedikleri elbette birbirlerinin dikkatini çekmektedir. Yine bu durumun önüne geçmek için sınıf öğretmenleri, herkesin aynı gün aynı yemeği yemesi gibi birtakım önlemler alsa da bu konu da tamamen öğretmenlerin inisiyatifine bırakılmıştır. Öğrenciler uyum sınıfında değillerse okula ait olan üniformayı veya muadilini giymek zorundadırlar. Bu nedenle mont, ayakkabı gibi kişisel tercihe bırakılan kıyafetler veya okul formasının temiz olması, öğrencinin kişisel bakımını düzenli olarak yerine getirebilmesi gibi etkenler mülteci çocukların kendileri farkında olmasalar da aslında birtakım farklılıkları kapatabilmektedir. Mülteci çocukların az önce sayılan verilerinin Türkiyeli çocukların dikkatini çektiği gözlemlenmiştir. Yani Türkiyeli çocuklar, mülteci çocukların ders materyallerine ulaşım, zorunlu olmayan kıyafetler, beslenme saatlerinde tükettikleri besinler gibi gelir düzeylerini ortaya çıkartan fenomenlerin farkında olduklarını ancak bu durumun onlarla arkadaş olmakta bir engel olmadığını belirtmişlerdir. Hatta bu durum onları yardımlaşmaya sevk etmiş, Türkiyeli bir öğrenci ailesi ona mont alırken daha ucuz bir monttan iki tane alıp mülteci arkadaşına hediye etmek konusunda ısrarcı davranmıştır. Aynı şekilde beslenme saatinde kimi zaman mülteci arkadaşlarıyla besinlerini paylaştıklarını, mülteci arkadaşının da onunla besinini paylaştığı belirtilmiştir. Ancak bazı durumlarda temiz ve düzenli kıyafetlere ulaşım ve kişisel temizlik konusunda Türkiyeli çocukların, mülteci çocuklar hakkında olumsuz yorumları olmuştur.

İkinci kademede durum benzer ilerlese de bu defa çalışmak zorunda olan mülteci çocuk figürü karşımıza çıkmaktadır. Suriyeli çocukların okullaşmasının önündeki en önemli engel ailelerinin gelirleri düşük olduğundan çocukların çalışmak zorunda olmalarıdır (Taştan \& Çelik, 2017, p. 36). Mülteci çocukların aileleri bir işte çalışıyor olsalar dahi 
ücretlerin düşüklüğü kimi zaman çocukları çalışmaya itebilir. Ekonomik problemler yaşarken, hiç bilmedikleri bir ülkeye gelmişken, yakınlarını savaşta kaybetmişken ve bunların hepsini çocukken yaşamışken çalışmak zorunda olmanın onların ders başarısını olumsuz etkilediği su götürmez bir gerçektir. Yukarıda da belirtildiği gibi derste başarılı olmak bu çocukların eğitim sürecine ve arkadaşlık ilişkilerine dâhil edilmesinde önemli bir noktadır. Çalışma eylemi çoğunlukla kayıt dışı gerçekleşmektedir. Bu kayıt dışılık konu yabancılar olduğunda suç olmaktan çıkıp bir doğal durum gibi algılanabilmektedir (Akbaş, 2019). Örneğin bir öğrenci kardeşleri ile birlikte plastik toplamakta, bu plastikleri kilosu 50 kuruştan satmaktadır. Aynı zamanda bu plastikleri Türkiyeli vatandaşlar kilosunu 1 liradan satabilirken, onlar mülteci oldukları için 50 kuruşa sattıklarını söylemiştir. Yine bir başka öğrenci pazarda, bir pazarcının yanında tüm gün çalışıp karşılığında 1 lira aldığını ve bir daha işe gitmediğini söylemiştir. Durum böyle olunca aslında beden eğitimi dersinde spor ayakkabıya veya eşofmana ulaşamıyor olmak son derece normal bir durumdur ve öğrenciler bu konuda ciddi sıkıntılar yaşamaktadır. Hatta birinci ve ikinci kademedeki beden eğitimi öğretmenlerinin neredeyse tamamı eşofman ve spor ayakkabı almaları konusunda oldukça israrcı davranmaktadır. Ancak en ucuz spor ayakkabı ve eşofmana toplamda 50 lira ödeyecek olan bu çocukların bu ürünlere erişimi için ya $100 \mathrm{~kg}$ plastik toplayıp satabilmeleri ya da 50 gün bir pazarcının yanında çalışmaları gerekmektedir! Bunun dışında ikinci kademede beslenme saati olmasa da çoğunlukla öğle arası vardır ve öğle arasında mülteci öğrenciler eve gelip evde yemek yediklerini, okul uzak ise okulda kaldıklarını ancak eve gelince yemek yediklerini ifade etmişlerdir. Burada yine mülteci çocuklar ayrıma uğradıklarını düşünmemektedirler. Nitekim beden eğitimi öğretmenlerinin sadece kendilerine değil alamayan bütün arkadaşlarına aynı şeyi yaptığı veya yalnızca kendilerinin değil Türkiyeli öğrencilerin de bu konuda problemler yaşadıklarını ifade etmişlerdir.

Aynı verileri ikinci kademedeki Türkiyeli çocuklar da desteklemiş, ekonomi üzerinden bir ayrıma tabii tutmadıklarını belirtmiştir. Ancak yine bu dolaylı bir belirleyicidir. Teneffüs saatlerinde veya öğle aralarında mülteci çocuklarla bir arada olmamak, okul dışında yapılan aktivitelere katılamamak, okul içerisindeki kermes gibi, öğretmenler günü gibi birtakım organizasyonlarda aktif olamıyor olmak mülteci çocukların görünürlügüunü azaltmaktadır. Aynı durum üçüncü kademe öğrenciler için de geçerlidir. Mülteci çocuklar üçüncü kademede çalışmak, düşük gelir düzeyi, ders materyallerine erişim gibi bazı faktörlerde zorluklar yaşamakta ve bu onların görünürlüğünü azaltmaktadır.

Çocuk ve Medeniyet 2020/1
Gerçekçi olmak gerekirse aslında bu denli ciddi problemleri çocuk yaşta üstlenirken okulda yaşanan bu tür problemleri genellikle görmezden geldikleri düşünülmektedir. 


\section{Sonuç ve Öneriler}

"Farkl toplumsal gruplardan bireyler birbirleriyle temas kurdukça, önyargının temelinde yatan hatal genellemeler fark edilir, farklilılarn yan stra benzerlikler keşfedilir, 'öteki' grubun aslında sanıldığı kadar 'kötü' ve 'homojen' olmadığı görülür. Kısacası, bireyler birbirinin gözünde 'insanlaşır;' belli bir grubun üyesi olmaktan ziyade insani özellikleriyle ön plana çıkarlar"(Gürkaynak, 2012, p. 257). Çocuklar özelinde ön yargıların zaten oldukça az olduğunu fakat öğretim kademesi arttıkça "ötekinin” insani özelliklerini görmekten çok ön yargıların güçlendiğini söyleyebiliriz. Bu durum belki de Türkiyeli öğrenci ile mülteci öğrenci arasındaki en büyük sorun olabilir. Öğrenim kademesi arttıkça çocuklar arasındaki ilişkiler toplumsallaşmaya bağlı olarak artmıştır. "Mülteci arkadaştan", "vatanında savaşmayan Suriyeliye” olan dönüşüumde aslında arada birçok faktörün etkili olduğu görülmektedir. Bu faktörlerden en bariz olanı iletişimin yegâne aracı olan dildir. Dilin kullanımı ve dilin yaşayan bir unsur olarak kullanımının yanı sıra ders başarısı, öğretmen, aile, akran grupları gibi sosyal çevrenin etkisi bu değişimin önemli unsurlarındandır. Bunun yanı sıra mülteci öğrencilerin kamusal alanda görünürlügüüü etkileyen faktörler onların uyum sürecini etkilemektedir.

İki farklı grubun sosyal temasında öncelikle bireysel karşılaşmalardan kazanılan deneyimler ön plana çıkar. Araştırmaya katılan öğrenciler için sınıfındaki mülteci öğrenci bütün mültecileri temsil etmektedir. Bu, bazı durumlarda ayrımcılığı körükleyebilecekken bazı durumlarda da uyum imkânı yaratmaktadır. Yanlış genelleme, bireysel deneyimlerden bütün bir gruba yapılırken aslında mülteci öğrencilerin üzerine düşen sorumluluk büyüktür. Hiyerarşik ilişkide iki farklı grup karşılaştığında söylemi genellikle hâkim grup oluşturur. Yani bugün Suriyeliler üzerine konuştuğumuzda Suriyeliler hakkındaki söylemlerimiz "bizler" tarafından üretilmiş söylemlerdir. Suriyeliler kamusal alanda kendi sözlerini söyleyebilecek durumda değillerdir çünkü her biri birer ötekidir. Ayrımcılık her zaman doğrudan görülebilir bir kavram değildir.

Ayrımcılığı önlemek için öncelikle eşitlik bilincinin içselleştirilmesi gerekmektedir. İnsan hakları kavramının çocuklara eğitim sistemi içerisinde bütün kademelerde anlatılması ve insanların birbirleriyle kurdukları ilişkilerin insanlık çatısında kurulması gerektiği önemli bir adım olacaktır. Aynı zamanda savaşın yıkıcı etkileri ve özellikle iç savaş söz konusu olduğunda insanların göç edebileceği konusunda öğrenciler bilgilendirilmelidir. Nitekim göç sadece savaşın bir sonucu değildir 
savaştan dolayı vatandan göç etmek, bu kutsal anlama ihanet anlamına gelebilmektedir. Dolayısıyla göç eden kişiler "vatanına ihanet eden" kötü kişiler olabilmekte, buna göre yargılanabilmektedir. İşte bu durumun önüne geçmek için göç, savaş, iç ve dış savaş, göçmen, sığınmacı, geçici koruma statüsü, mülteci gibi kavramlar, uluslar arası göç hukuku, göçmen hakları gibi hak ve görevler kademelere uygun düzeyde anlatılmalı, öğrenciler gerçekliği olmayan bilgilere karşı sorgulayıcı ve eleştirel davranmaları konusunda uyarılmalılardır. Çocuklar, bu toplumdan bağımsız varlıklar değillerdir ve toplumun kurumlarına, kavramlarına, değer ve kültürüne duyarlılardır. Bu nedenle içinde yaşadıkları toplumdaki tehlike, yabancı, öteki gibi kavramları hiç sorgulamadan öğrenebilmektedirler. Suriyeliler de kimi zaman yabancılığın getirmiş olduğu ötekileştirmeye bu vesile ile maruz kalabilmektedir. Dolayısıyla en azından eğitim sistemi içerisinde öğrencilerin eğitim sürecinden maksimum verim alabilmeleri için ayrım ve nefret yaratabilecek söylemlere karşı bilinçlendirilmelidirler. Derslerin, ders içeriklerinin ve müfredat içerisindeki konuların ayrımı destekleyici, pekiştirici ya da ayrım yaratıcı bir dilden uzak olması ve böyle bir durum söz konusu olduğunda öğretmenlerin bu argümanları ayrımcı dilden uzak biçimde öğretmesi önemlidir. Öğretmenin kendi ideolojik tutumu veya dünya görüşünden bağımsız bir ders ortamı yaratması, açık veya gizli nefret söylemleri oluşturabilecek tavır takınmaması ve aslında öğretmenlerin de göç ve göç hukuku, göç eden kişilerin hakları gibi konularda bilinçlendirilmesi, eşitlik ve insan haklarına karşı duyarlı olmaları son derece önemlidir. Olası problemleri etkin bir şekilde çözmek, uyum sürecinin sağlıklı işlemesini sağlamak, öğrencilere eğitimde firsat eşitliğini yaratmak konusunda en önemli rolün öğretmenlerde olduğu düşünülmektedir.

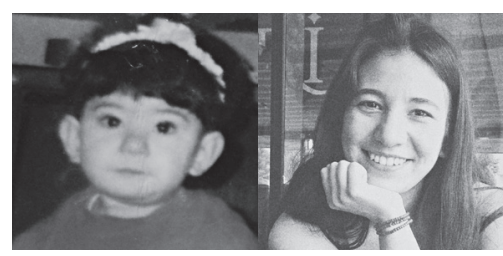

Lutfiye Aktan

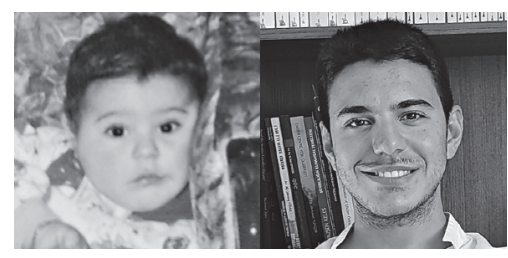




\section{Kaynakça}

Akbaș, E. (2019). Türk yazılı basınında Suriyeli sığınmacı çocuklar. Cocuk ve Medeniyet, 4(8), 159- 171

Akbaș, E. ve Erükçü Akbaș, G. (2019). Çocukluk sosyolojisinin özgün sahası: Çocuklarla nitel araștırma. Cocuk ve Medeniyet, 4(7), 149-161.

Althusser, L. (2017). İdeoloji ve devletin ideolojik aygıtları. (çev. A. Tümertekin.) İstanbul: Ithaki .

Apple, M. (2006). Eğitim ve iktidar.(çev. S. Tanrıverdi ve E. Bulut.) İstanbul: Kalkedon Yayınları .

Baker, C. (2000). Zorunlu eḡitime hayır. (çev. A. Sönmezay .) İstanbul: Ayrıntı Yayınları .

Bauman, Z. (2018). Sosyolojik düșünmek .(çev. A. Yılmaz.) İstanbul: Ayrıntı Yayınları.

Birleșmiș Milletler Mülteciler Yüksek Komiserliḡi Türkiye Temsilciliḡi. (1998). Sıḡınma ve mülteci konularındaki uluslararası belgeler ve hukuki metinler. Ankara: Damla Matbaası .

Cayır, K. (2014). Biz kimiz? Ders kitaplarında kimlik, yurttașık ve haklar. İstanbul: Tarih Vakfı YayınlarıSeçbir Yayınları .

Çiçeksögüt, A. (2017). Uluslararası göç hukuk perspektifinde yerinden edilmiş Suriyelilerin Türkiye deki statüsü. Kırklareli Üniversitesi Iktisadi ve Idari Bilimler Fakültesi Dergisi ,6(2), 1- 20.

Goffman, E. (2004). Günlük yașamda benliḡin sunumu .(çev. B. Cesar.) İstanbul: Metis Yayınları .

Göç İdaresi Genel Müdürlüḡü. (2020). İstatistikler, göç alanındaki güncel sayılar. Mart 5, 2020 tarihinde T.C. İçișleri Bakanlığı Göç İdaresi Genel Müdürlüğü: https://www.goc.gov.tr adresinden alındı

Gürkaynak, E. C. (2012). Toplumsal temas: Önyargı ve ayrımcılığı önlemek için bir sosyal deḡișim aracı olarak kullanılabilir mi? (der. K. Cayır ve M. Ayan Ceyhan), Ayrımcılık: Cok Boyutlu Yaklașımlar içinde (s. 255-265). İstanbul : İstanbul Bilgi Üniversitesi Yayınları .

Illich, I. (2006 ). Okulsuz toplum .(çev. C. Öner.) İstanbul : Oda Yayınları .

İsmail, S., Kahraman, Ö. F., ve Aydın, A. (2018). Türkiye'deki Suriyeli nüfusun hukuki statüsü ile ilgili bir analiz. Turkish Studies, 13(7), 383-396.

Karakaș, K., ve Șahin, R. (2017). Șiddet ve zorbalığı önleme yolları. (ed. M. Baloḡlu, E.Göv ve T. Baḡrıaçık) Geçiçi Koruma Statüsündeki Bireylere Yönelik Rehberlik Hizmetleri Kılavuz Kitabıiçinde (s. 132). Ankara: MEB.

Kılıç, Y. T. (2008). Wilhelm von Humboldt'ta ulusal kimlik ve dil sorunsalı: Yabancılığın içinden bütüne ulașma çabası. Doktora Tezi, Okan Üniversitesi- Almanca Mütercim Tercümanlık Anabilim Dalı, İstanbul. 41- 57.

Mavi Kalem Sosyal Yardımlașma ve Dayanıșma Deneḡi. (2019). Suriyeli çocukların eḡitimi araștırma raporu . İstanbul: Mavi Kalem.

Özger, B. Y., ve Akansel, A. (2019). Okul öncesi sınıfındaki Suriyeli çocuklar ve aileleri üzerine bir etnografik durum çalıșması: Bu sınıfta biz de varız! Eğitimde Nitel Araștırmalar Dergisi , 7(3), 942966.

Özyürek, A., Kapçı, P. E., ve Yılancı, S. (2019). Farklı yaş grubundan bireylerin Türkiye deki Suriyeli mültecilerin durumu hakkındaki görüşlerinin incelenmesi. MSKU Eğitim Fakültesi Dergisi, 7 6(1), 56-69.

Suriyeli Cocukların Türk Eḡitim Sistemine Entegrasyonunun Desteklenmesi Projesi [PIKTES]. (2017). Projenin kapsamı . Mart 1, 2020 tarihinde: https://piktes.gov.tr adresinden alındı

Punch, K. (2016). Sosyal araștırmalara giriș. Ankara: Siyasal Yayınevi.

Șahin, R., ve Karakaș, K. (2017). Çok kültürlülük ve çok kültürlü danıșma. (ed. M. Baloḡlu, E. Göv ve T. Baḡrıaçık) Geçiçi Koruma Statüsündeki Bireylere Yönelik Rehberlik Hizmetleri Kılavuz Kitabı içinde (s. 82-95). Ankara: MEB.

T.C. Milli Eḡitim Bakanlığı ve Unicef. (2017). Geçici koruma stasündeki bireylere yönelik özel eḡitim kılavuz kitabı. Ankara: MEB.

Eğitimin Milliyeti: Mülteci Öğrenciler ve Türkiyeli Öğrencilerin Kademelere Göre Değişen Öğrencilik Deneyimleri 
T.C. Milli Eḡitim BakanlıḡıHayat Boyu Öḡrenme Genel Müdürlüḡü. (2020) Geçici koruma kapsamı. https://hbogm.meb.gov.tr/ adresinden alındı.

Tanhan, F. (2017). Geçici koruma statüsündeki bireylerde ölüm ve yas. (ed. M. Baloḡlu, E. Göv ve T. Baḡrıaçık) Geçiçi Koruma Statüsündeki Bireylere Yönelik Rehberlik Hizmetleri Kılavuz Kitabı içinde (s. 106-116). Ankara: MEB.

Taștan, C., ve Çelik, Z. (2017). Türkiye'de Suriyeli çocukların ēgitimi: Güçlükler ve öneriler. Ankara : Eḡitim Bir- Sen Stratejik Araștırmalar Merkezi. 